2007-01-01

\title{
Preserving deep-sea natural heritage: Emerging issues in offshore conservation and management
}

\section{Davies, AJ}

http://hdl.handle.net/10026.1/1350

10.1016/j.biocon.2007.05.011

Biological Conservation

Elsevier BV

All content in PEARL is protected by copyright law. Author manuscripts are made available in accordance with publisher policies. Please cite only the published version using the details provided on the item record or document. In the absence of an open licence (e.g. Creative Commons), permissions for further reuse of content should be sought from the publisher or author. 


\title{
Review
}

\section{Preserving deep-sea natural heritage: Emerging issues in offshore conservation and management}

\author{
Andrew J. Davies ${ }^{a, *}$, J. Murray Roberts ${ }^{a}$, Jason Hall-Spencer ${ }^{b}$ \\ aScottish Association for Marine Science, Dunstaffnage Marine Laboratory, Oban, Argyll PA37 1QA, UK \\ ${ }^{\mathrm{b}}$ Marine Biology and Ecology Research Centre, School of Biological Sciences, University of Plymouth, Drake Circus, Plymouth PL4 8AA, UK
}

\section{A R T I C L E I N F O}

Article history:

Received 21 December 2006

Received in revised form

14 May 2007

Accepted 17 May 2007

Available online 17 July 2007

Keywords:

Hydrocarbons

Deep-sea fishing

Vessel monitoring system

Ocean acidification

Climate change

Marine protected areas

Lophelia pertusa

\begin{abstract}
A B S T R A C T
Human activity in the deep sea is extending ever deeper, with recent research showing that this environment is more sensitive to human and natural impacts than previously thought. Some deep-water fish stocks have collapsed and fishing methods such as bottom trawling have raised international concern over the habitat damage they cause. It is likely that in its current form, deep-sea fishing is unsustainable. Diminishing reserves of hydrocarbons in shallow water are pushing exploration and production into deeper waters, which may cause damage to little known deep-sea habitats. The deep sea is also proposed as an environment where anthropogenic carbon dioxide could be stored to minimise the effect of its release into the atmosphere. At the same time, rising atmospheric carbon dioxide levels may be altering the chemical equilibrium of the global ocean by lowering $\mathrm{pH}$. Many countries are now beginning to designate some deep-sea habitats as marine protected areas in measures to reduce the damage caused by fishing and other anthropogenic activities. This review examines these current and emerging issues in deep-sea conservation and discusses conservation status and the designation of protected areas. The enforcement of protected areas using satellite tracking of vessels is discussed and applied to an internationally agreed deep-water conservation area, which aims to protect cold-water coral habitats on the Darwin Mounds in the north east Atlantic Ocean.
\end{abstract}

(c) 2007 Elsevier Ltd. All rights reserved.

\section{Contents}

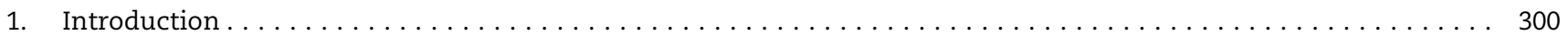

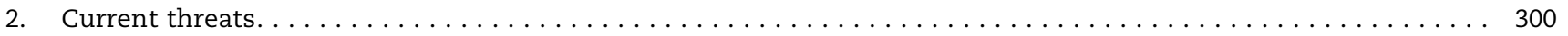

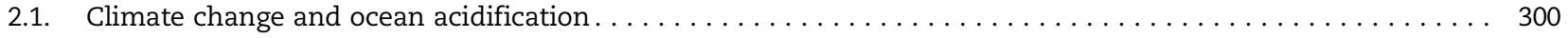

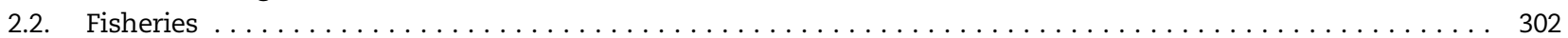

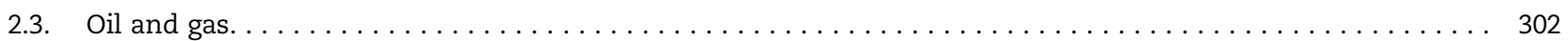

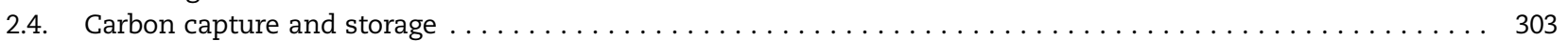

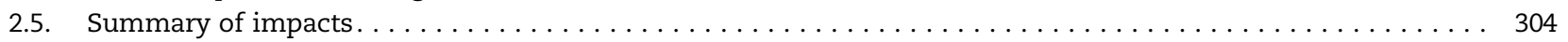

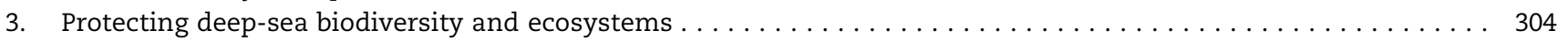

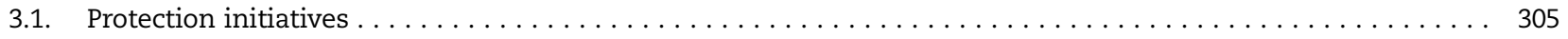

* Corresponding author: Tel.: +44 01631 559019; fax: +44 01631559001.

E-mail address: andrew.davies@sams.ac.uk (A.J. Davies).

0006-3207/\$ - see front matter @ 2007 Elsevier Ltd. All rights reserved.

doi:10.1016/j.biocon.2007.05.011 


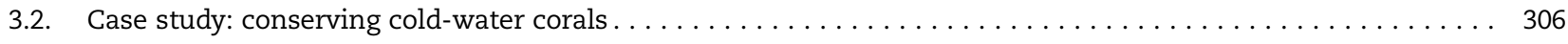

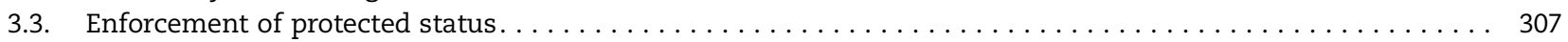

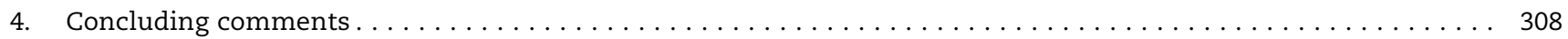

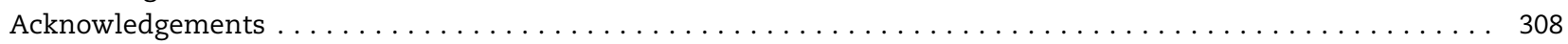

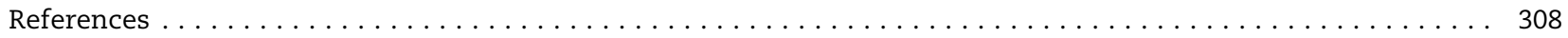

\section{Introduction}

Waters of over $1000 \mathrm{~m}$ deep cover an estimated $62 \%$ of the surface of the earth, forming one of the last great wilderness areas on the planet (Roberts, 2002a). Only within the last few decades has technology advanced sufficiently to map the deep sea effectively (Diaz et al., 2004), revealing extensive and diverse habitats of conservation interest and economic value (Tunnicliffe, 1991; Rogers, 1999; Hovland et al., 2002; Roberts et al., 2005b). Concurrently, human activity, most notably fishing, has continually expanded from coastal waters with great increases in the amount of activity and depths of operations since the 1950s (Morato et al., 2006). Fishing activities are increasingly affecting the deep ocean, to the extent that quantifiable changes in fish stocks (Baum et al., 2003; Morato et al., 2006) and damage to benthic habitats (Roberts et al., 2000; Koslow et al., 2001; Hall-Spencer et al., 2002; Gage et al., 2005; Wheeler et al., 2005) have now been recorded around the world.

Many deep-sea areas (>200 m after Gage and Tyler, 1991) are found beyond the exclusive economic zone of individual nations on the High Seas. Under the Third United Nations Convention on the Law of the Sea (UNCLOS; UN, 1982), the High Seas are an open-access commons where all nations have the right to engage in fishing (UNCLOS, Article 87). With no clear ownership or jurisdiction, these areas are potentially vulnerable to over-exploitation and unregulated activities. However, there are provisions for conservation within the UNCLOS, with nations required to cooperate in the conservation of living marine resources of the High Seas (UNCLOS, Articles 116-120). One development from the UNCLOS (and subsequent supplementary agreement on the implementation of Part XI in 1996; UN, 1996) was the genesis of the International Seabed Authority which regulates all solid, liquid or gaseous mineral resources at or beneath the seabed in the High Seas. Unfortunately, the majority of legal provisions laid out within the UNCLOS have not yet been developed into a sufficiently comprehensive framework to efficiently manage the majority of resources in the High Seas (FAO, 2004).

The lack of incentives for nations to constrain fishing effort and comply with conservation measures on the High Seas raises concern over the absence of effective international measures for assessing and protecting newly discovered habitats (FAO, 2004). The deep sea contains many distinct habitats including hydrothermal vents, cold seeps, seamounts and cold-water coral reefs amongst the expanses of abyssal muds, themselves home to a notably rich animal community (Grassle and Maciolek, 1992; Gage, 1996).

\section{Current threats}

Anthropogenic threats can be either direct, such as fishing or hydrocarbon exploitation or indirect, such as increasing atmospheric $\mathrm{CO}_{2}$ levels leading to changes in the chemistry of the ocean. This review summarises emerging threats to deep-sea ecosystems (e.g. climate change) and provides recent evidence to update the threats reviewed by Glover and Smith (2003) (e.g. fisheries, oil and gas and carbon capture and storage). Several significant threats are omitted due to coverage in earlier reviews (e.g. dumping and mining) but this does not mean these threats are not severe. The mining of deep-sea mineral resources is imminent, with licenses already being provided by the International Seabed Authority (ISA, 2006). This review closes by discussing protection and enforcement initiatives using a cold-water coral ecosystem case study.

\subsection{Climate change and ocean acidification}

Numerous studies have reported changes in global climate (e.g. IPCC, 2001) with many significant effects recorded in organisms throughout the world (e.g. Scheffer et al., 2001; Walther et al., 2002). Previously, the deep sea was thought to be buffered against the effects of surface-driven cycles and impacts (Menzies, 1965), but modern research has now shown the deep-sea to be susceptible to changes at the surface. These observations include variation in physical processes such as currents and seasonal influxes of particulate matter, as well as variation in ecological processes such as reproduction, growth rate and oxygen consumption (e.g. Tyler, 1988; Gooday, 2002). Several impacts on the surface could have implications for deep-sea habitats and organisms. Changes in surface productivity and environmental variables such as temperature or salinity could potentially influence deep-sea species distribution, abundance and behaviour (Levin et al., 2001; Ruhl and Smith, 2004). Increasing fresh water input from terrestrial sources may disrupt thermohaline circulation, changing ocean circulation patterns and affecting water temperature and density (Hansen et al., 2004). In the deep Eastern Mediterranean Sea, between 1992 and 1994, abrupt changes in water temperature and density led to a rapid change in the nematode community. There was a significant decrease in the abundance of some genera but an overall increase in species diversity (Danovaro et al., 2004). Even abrupt, short-term changes in environmental conditions at the seafloor may have longterm effects on the composition and functioning of deepsea ecosystems.

Surface productivity, especially from phytoplankton and zooplankton has been strongly linked to climatic fluctuations (Edwards et al., 2001; Hawkins et al., 2003; Schippers et al., 2004; Pitois and Fox, 2006). In the North East Atlantic phytodetrital deposits during spring and early summer deliver an estimated $2-4 \%$ of spring-bloom surface production to the seafloor (Gooday, 2002). This usually consists of fresh phytoplankton and a high proportion of diatoms as well as other 
biogenic particles, forming an important and recurrent source of matter to the deep sea (Lampitt, 1985; Turley et al., 1995). Within days of the arrival of phytodetritus, there are large increases in the biomass and activity of protozoans and bacteria (Graf, 1989; Soltwedel, 1997). Over the following weeks, increases in the abundance and biomass of Foraminifera, metazoan meiofauna and epibenthic megafauna have been recorded (Pfannkuche, 1992, 1993; Bett et al., 2001; Hughes and Gage, 2004). Changes in the distribution of productivity on the surface would likely alter the distribution of species on the seafloor. In the deeper waters of the North Pacific, declines in food supply from surface waters has led to decreased community oxygen consumption and continued disruption is expected to lead to changes in the structure and dynamics of these communities (Smith and Kaufmann, 1999). One enigmatic group of deep-sea organisms, cold-water corals, have been strongly linked with areas of high surface productivity and accelerated currents (Rogers, 1999; Guinotte et al., 2006; Roberts et al., 2006b), any disruption to surface patterns may have negative effects on these and other deep-sea habitats (Ruhl and Smith, 2004).

A key emerging issue has been the recent prediction that the chemistry of the oceans will change due to rising concentrations of anthropogenic $\mathrm{CO}_{2}$ in the atmosphere. The global ocean is a substantial reservoir of carbon, containing about 38,000 gigatonnes of carbon (Gt C), compared to $700 \mathrm{Gt} \mathrm{C}$ in the atmosphere and $2000 \mathrm{Gt} C$ in terrestrial systems (Brovkin et al., 2002). When atmospheric carbon in the form of $\mathrm{CO}_{2}$ is absorbed by the ocean it becomes reactive and produces hydrogen ions due to an initial reaction with $\mathrm{H}_{2} \mathrm{O}$, forming carbonic acid $\left(\mathrm{H}_{2} \mathrm{CO}_{3}\right)$, this has the effect of making the ocean more acidic (Raven et al., 2005). Globally, the surface ocean has an average $\mathrm{pH}$ of 8.2 units $( \pm 0.3$ units due to local, regional and seasonal factors; Raven et al., 2005). Observations and models have found that the average $\mathrm{pH}$ of the ocean has declined by 0.1 units since preindustrial times and is projected to decrease by $0.3-0.7$ units under the IPCC IS92a scenario by the end of the century (Brewer, 1997; Caldeira and Wickett, 2003). Such large scale changes are greater than any over the past 300 million years (Caldeira and Wickett, 2003). The age of "ocean acidification" may have begun.

Current geochemical models predict that as well as acidification, further changes will occur in chemistry of the oceans (Caldeira and Wickett, 2005; Orr et al., 2005). Carbon that is dissolved in seawater exists in three main inorganic forms, collectively known as dissolved inorganic carbon (DIC). (1) Aqueous $\mathrm{CO}_{2}\left(\mathrm{CO}_{2}(\mathrm{aq})\right)$, (2) bicarbonate $\left(\mathrm{HCO}_{3}^{-}\right)$and (3) carbonate ions $\left(\mathrm{CO}_{3}^{2-}\right)$. The most abundant form is bicarbonate, followed by carbonate ions and then $\mathrm{CO}_{2}(\mathrm{aq})$. These forms of dissolved carbon act as a natural buffer and maintain the $\mathrm{pH}$ of seawater within natural limits (see Annex 1 in Raven et al., 2005). An acidified ocean is characterised by an increase in $\mathrm{CO}_{2}(\mathrm{aq})$, hydrogen ions and $\mathrm{HCO}_{3}^{-}$and a decrease in $\mathrm{pH}$ and $\mathrm{CO}_{3}^{2-}$ concentration. The effect of ocean acidification is most pronounced at the surface, with organisms in shallow waters likely to be affected first (see reviews by Raven et al., 2005; Haugan et al., 2006; Kleypas et al., 2006). Initially, the photosynthetic rate of some phytoplankton species may increase due to increased $\mathrm{CO}_{2}$ availability (Beardall and Raven, 2004; Schip- pers et al., 2004) but this could be offset in the longer term with impacts on growth and community composition of phytoplankton (Raven et al., 2005). However, there is a general lack of conclusive data for the majority of phytoplankton groups.

Coccolithophores and other calcifying planktonic organisms are an important source of calcium carbonate $\left(\mathrm{CaCO}_{3}\right)$ to the deep-sea floor and are important in marine carbon cycles and ocean-atmosphere $\mathrm{CO}_{2}$ exchange (Milliman, 1993). Calcifying marine plankton grown under simulated future acidified ocean conditions are unlikely to maintain presentday production levels, due to slowing of calcification and growth (Riebesell et al., 2000; Zondervan et al., 2001). Surface calcification is a major source of ballast for the transport of organic carbon to the deep-sea. Under modelled ocean conditions the production of these calcifying organisms could decrease by as much as $50 \%$ from pre-industrial values 250 years from now (Heinze, 2004). Not only would this remove a major carbon sink and an important source of organic carbon to the deep-sea floor but it would impact the ability of the ocean to buffer $\mathrm{CO}_{2}$ absorption. This may lead to a potential increase in carbon uptake in surface waters under IS92a scenarios (Riebesell et al., 2000).

A major group of deep-sea organisms that could be affected by ocean acidification are cold-water corals (Turley et al., in press). Cold-water coral reefs are important habitat for a wide variety of species (Roberts et al., 2006b), and may form essential fish nursery and feeding grounds (Husebø et al., 2002). The present day distribution of cold-water coral reefs largely reflects the parts of the ocean that are supersaturated with respect to aragonite (Guinotte et al., 2006). In seawater, $\mathrm{CaCO}_{3}$ can be fixed into two forms, aragonite and calcite (calcite is the less soluble of the two), the stability of each form is governed by the amount of free $\mathrm{CO}_{3}^{2-}$, temperature, salinity, pressure and a stoichiometric solubility product for each form (Feely et al., 2004). The depth boundary where seawater becomes undersaturated with respect to aragonite and calcite is known as the saturation horizon. Organisms that utilise $\mathrm{CaCO}_{3}$ skeletons or plates become hindered in growth and biogenic structures become vulnerable to dissolution below the saturation horizon (Feely et al., 2004; Orr et al., 2005; Guinotte et al., 2006; Kleypas et al., 2006). The majority of records of reef framework-forming cold-water corals are from the North Atlantic Ocean, where the aragonite saturation horizon (ASH) is much deeper than in the Pacific (Orr et al., 2005). The shoaling of the ASH in the Pacific restricts the formation of aragonite skeletons to shallower waters. In the Pacific, coral communities are dominated by solitary octocorals and hydrocorals, a contrast to the large scleractinian reef structures in the North Atlantic (Guinotte et al., 2006). Models of the projected aragonite saturation show that ca. $70 \%$ of current known cold-water coral locations could become undersaturated by 2099 , with the vast majority of the remaining $30 \%$ restricted to the North Atlantic (Guinotte et al., 2006).

Currently, only about $7 \%$ of the total anthropogenic $\mathrm{CO}_{2}$ found in the ocean has penetrated deeper than $1500 \mathrm{~m}$ (Sabine et al., 2004), but the effect of climate change in the deep sea has now been recorded in several studies. The deep-sea areas or species that are likely to be most affected by climate change are those that rely on food supply from surface waters, calcifying marine organisms or those that have 
specific environmental tolerances to variables such as salinity or temperature (Smith and Kaufmann, 1999; Danovaro et al., 2001, 2004; Ruhl and Smith, 2004; Guinotte et al., 2006). Yet, there is still a clear need for comprehensive research into the effect of climate change in the deep sea.

\subsection{Fisheries}

In the 1950s and 1960s the deep-water fishing industry expanded rapidly following a decline in catches from the traditional fisheries of shelf seas (Koslow et al., 2000; Roberts, 2002a). This shift in effort also coincided with improvements to fishing gear and the development of large, refrigerated vessels capable of spending extended periods at sea. Since 1950 the mean depth of fishing in the North Atlantic Ocean has increased by $32 \mathrm{~m}$ per decade as fishermen continually seek to fish unexploited areas which usually lie in deeper waters (Morato et al., 2006). This coincided with recorded declines in the diversity of some fisheries. For example, the diversity of High Seas predatory fishes are estimated to have declined between 10 and 50\% since 1950 (Worm et al., 2005).

Surprisingly, catch statistics from deep-sea fisheries have appeared relatively stable until recently, disguising the decline of individual species as fishermen serially exploit unfished species when faced with diminishing catches (Koslow et al., 2000). It is now evident that many deep-sea fisheries have collapsed or are beginning to show warning signs of population decline (Baum et al., 2003; Devine et al., 2006). The inherently low recovery potential of deep-sea fish and the practice of serial depletion (e.g. targeting spawning aggregations of fish; Roberts, 2002a) have over-exploited some fisheries to a level which cannot be sustained (Berkes et al., 2006). Some deep-sea fish species now meet the World Conservation Union's (IUCN) criteria for being critically endangered (Devine et al., 2006).

Fishing methods in the deep sea are largely unselective of the species caught, leading to a high amount of discarded bycatch. Deep-sea tangle and gillnet fishing has been the recent focus of several European Union studies (Pawson, 2003; Hareide et al., 2005). Currently, approximately 50 vessels in the North East Atlantic target mostly monkfish and deepwater sharks (Hareide et al., 2005). Whilst this fishery is largely unregulated and poorly understood, there are concerns over the "ghost" fishing of lost nets and the high amount of bycatch and discards relative to the amount of catch (Hareide et al., 2005). In shallower waters (<100 m), the majority of nets rapidly lose their catching efficiency within a month of being lost (Pawson, 2003). Nets lost in deeper waters may continue to fish over much longer periods due to the relatively low current energy. For example, nets between 117 and $135 \mathrm{~m}$ continued to catch monkfish efficiently for 135 days, with the nets ceasing to capture fish after 224 days (Sancho et al., 2003). Currently, no substantial long-term research has been conducted on the effect of "ghost" fishing nets in the deep sea, but these nets are expected to stabilise to approximately $20 \%$ of the initial catch after 45 days (Humborstad et al., 2003) but may fish for periods of at least 2-3 years and may even do so for longer periods (Furevik and Fosseidengen, 2000).

In terms of global effort, reported deep-water landings accounted for $6.5 \%$ of total fisheries capture in $2002(4.7 \%$ excluding China due to uncertainty in reporting statistics), a small proportion of a global industry worth between $\$ 70$ and $\$ 80$ billion (USD) year ${ }^{-1}$ (FAO, 2004). Deep-sea bottom trawling, one of the most physically damaging fishing methods, is not likely to exceed a value of $\$ 300-400$ million annually and contributes an estimated $0.2-0.25 \%$ of global fisheries capture weight (Gianni, 2004). The trawls used in the deep sea are modified forms of shallow water trawls, sometimes fitted with rock-hopper gear and kept open by large otter boards (or trawl doors) that can weigh up to a tonne each. On some occasions the base of the net is reinforced by chains, which serve to strengthen the net, adding weight to maintain close contact with the seafloor. On an average fishing excursion, these trawls are deployed for approximately $4 \mathrm{~h}$, sweeping 20-30 km of seabed at 3-5 knots. There can be up to 5 hauls day ${ }^{-1}$, and fishing excursions often last approximately 10 days, potentially covering up to $100 \mathrm{~km}^{2}$ of seafloor (Hall-Spencer et al., 2002). The practice of bottom trawl fishing is causing international concern due to the damage that occurs to benthic habitats during the passage of a trawl (e.g. Hall-Spencer et al., 2002; Gage et al., 2005).

One of the key differences between deep sea and shallow waters is the persistence of trawling damage. The deep sea in general is characterised by low current speeds and sedimentation rates resulting in the long-term persistence of trawling damage to the seabed (Gage et al., 2005), although there are some exceptions (e.g. coarse sediments that are less stable than muddy, sandy sediments; Roberts et al., 2000; Ball et al., 2000). Regardless of the ecosystem, trawling scrapes and ploughs the sediment, creating areas of intense disturbance (Roberts et al., 2000, see Fig. 1) and in the process rolls large boulders, removing any epifauna (McAllister et al., 1999; Gage et al., 2005). The passage of the trawl can also resuspend large quantities of sediment (Palanques et al., 2001, 2006), which smothers organisms and reduces the abundance of some components of the benthos (Yamazaki et al., 1997). The most significant and potentially persistent effect of trawling may be the damage of non-target epibenthic species such as sponges, xenophyophores and cold-water corals (Pitcher et al., 2000; Roberts et al., 2000; Koslow et al., 2001; Fosså et al., 2002; Hall-Spencer et al., 2002; Wheeler et al., 2005), but the long-term effects on marine organisms other than corals are largely unknown (Gage et al., 2005).

\subsection{Oil and gas}

Oil and gas extraction has been undertaken for many years in shelf seas but in recent years production has started to diminish (Kemp and Stephen, 2005). With continually increasing consumer demand and extraction costs some international hydrocarbon companies are now under significant pressure to discover new reserves (Hallock et al., 2004). A promising source of new reserves may be in deeper waters. Exploitation of deep-sea hydrocarbons began in the Gulf of Mexico in 1979, with six producing wells by 1992. This number rose to 17 by 1997 and increased exponentially to 118 by March 2006 mostly between 500 and $1500 \mathrm{~m}$ water depths (French et al., 2006). The Gulf of Mexico now contains the deepest well to date, the Toledo well drilled at $3051 \mathrm{~m}$ water depth in late 2003. There is further potential for large reserves to be exploited in deep- 

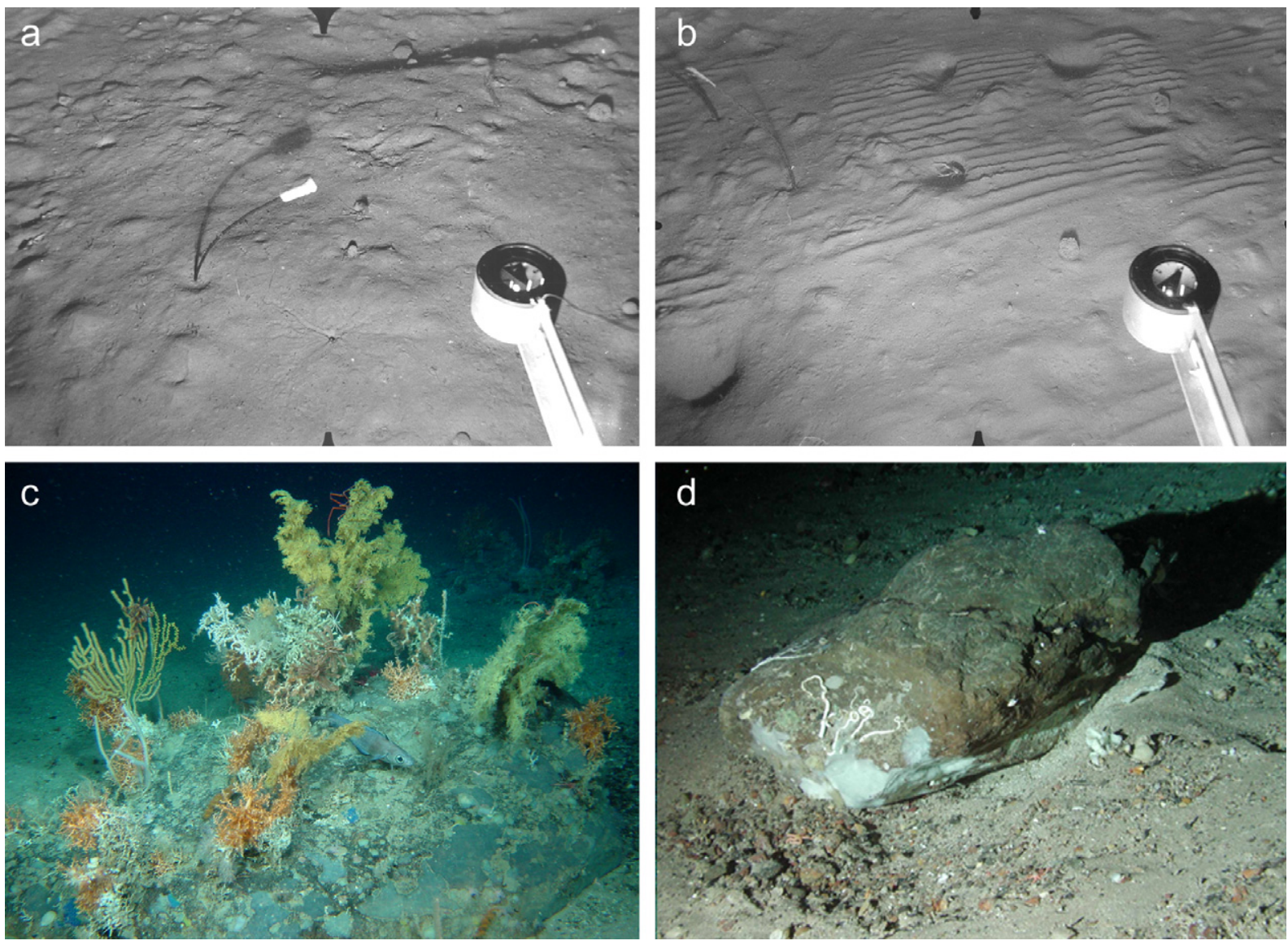

Fig. 1 - Images showing the effects of bottom trawling on benthic habitats. (a) Untrawled soft sediment with intact glass sponge (Hyalonema sp.), $1295 \mathrm{~m}$. (b) Trawled soft sediment with broken glass sponge stalk, $1298 \mathrm{~m}$. See Roberts et al., 2000. (c) Untrawled dropstone with diverse coral and sponge epifauna, $970 \mathrm{~m}$ Porcupine Bank (Photo courtesy of IFEMER and AWI). (d) Trawled dropstone, 590 m. See Gage et al., 2005.

sea areas off the coasts of South Africa, West Africa, Brazil and the Indo-Pacific region including Malaysia, Indonesia, Brunei and India (Zhu, 2004). In many parts of the world, such as the North Atlantic, offshore activities are strongly regulated to reduce pollution and the amount of waste deposited on the seabed (Hartley, 2005). For example, in the UK, regulation has led to noticeable reductions in the levels of discharges recorded, including carbon dioxide $\left(\mathrm{CO}_{2}\right)$ emissions, chemical discharges and contaminated drill cuttings (UKOOA, 2005).

The ocean currents in the deep-waters surrounding deepsea exploration and production facilities would likely disperse the contaminants released. This would dilute the impact on deep-sea species and some species thought to be highly sensitive to drilling discharges may in fact show some resilience. For example, the cold-water coral Lophelia pertusa has been found growing on oil rigs in the North Sea (Bell and Smith, 1999; Roberts, 2002b; Gass and Roberts, 2006, see Fig. 2). The majority of colonies discovered on these rigs are in good condition. However, those observed growing close to discharge chutes have shown signs of contamination with some colonies suffering upwards of 30\% polyp mortality (Gass and Roberts, 2006). It is probable that any discharges from deep-sea rigs at the surface or in the water column would disperse in the surrounding ocean, but discharges at the seabed may persist due to the low dispersal that characterises many deep-sea habitats (UKOOA, 2002). If discharges do occur close to the seafloor, it is likely that smothering and potential mortality to epibenthic species such as corals would occur (Rogers, 1999). The lack of basic information on the biology and ecology of deep-sea species emphasises the need for research on the impacts of hydrocarbon exploitation in deeper waters.

\subsection{Carbon capture and storage}

At present, global estimates suggest up to 25 billion tonnes of $\mathrm{CO}_{2}$ are released into the atmosphere each year (Stephens and Van der Zwaan, 2005). One approach to mitigate rising $\mathrm{CO}_{2}$ levels may be to capture and store $\mathrm{CO}_{2}$ (referred to as carbon sequestration or carbon capture and storage - CCS) rather than releasing it into the atmosphere. This is an emerging technology that is currently expensive and difficult to implement (Stephens and Van der Zwaan, 2005). Carbon dioxide could be stored in underground geological formations including depleted oil and gas fields, deep aquifers, unminable coal seams and deep-sea sediments (Holloway, 2005; House et al., 2006). There is also the potential for liquefied $\mathrm{CO}_{2}$ to be stored in the deep sea, achieved by injecting liquefied $\mathrm{CO}_{2}$ into great depths. In November 2006, Contracting Parties to the London Convention (1972 and 1996) adopted amendments to Annex 1 of the 1996 Protocol to the Convention on the Prevention of 


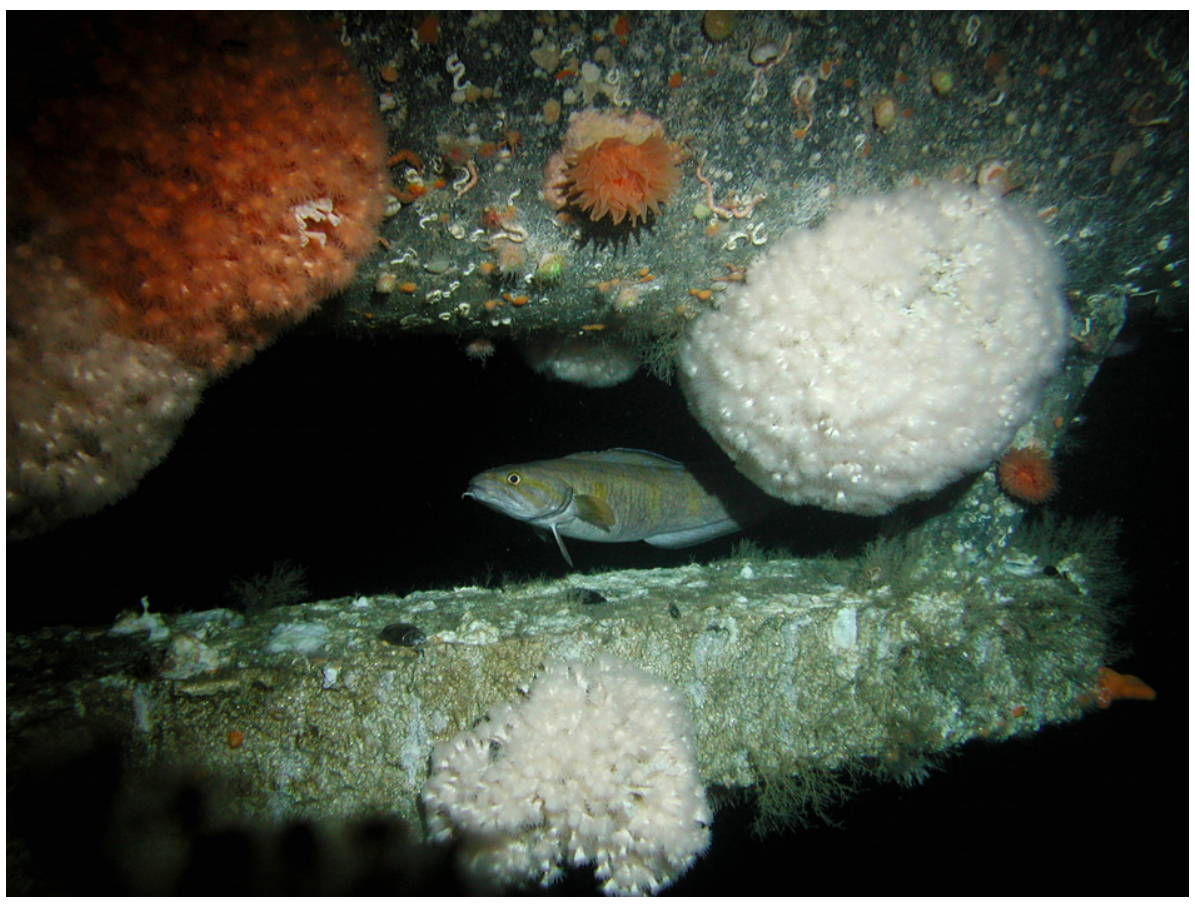

Fig. 2 - Dome-shaped colonies of Lophelia pertusa (red and white colonies), observed growing on an oil platform in the North Sea (Photo courtesy of Lundin Petroleum Ltd.). (For interpretation of the references to colour in this figure legend, the reader is referred to the web version of this article.)

Marine Pollution by Dumping of Wastes and Other Matter, 1972 (London Convention). This forms the legal basis allowing the sequestration of $\mathrm{CO}_{2}$ beneath the seabed.

It is likely that high concentrations of $\mathrm{CO}_{2}$ at injection points would have the most profound effects on deep-sea organisms (Barry et al., 2004). As currents disperse concentrated $\mathrm{CO}_{2}$, the lethal effects would most likely diminish with increasing distance from the source (Thistle et al., 2005). In situ experiments show the effects on deep-sea dwelling organisms can be profound (Seibel and Walsh, 2003). Benthic infauna and epifauna suffer respiratory stress and direct mortality from acidosis (Barry et al., 2004; Thistle et al., 2005, 2006). Mobile species may be able to move away from the $\mathrm{CO}_{2}$ source and thus only suffer temporary effects such as loss of consciousness (Brewer et al., 1999; Tamburri et al., 2000). Longer-term exposure may be lethal even for mobile species, but the observed effects do vary widely between species (Ishimatsu et al., 2005). The benefits gained by storing carbon dioxide in this way needs to be assessed in relation to the hazards it poses to deep-sea life (Barry et al., 2004).

\subsection{Summary of impacts}

With so much evidence of anthropogenic impacts on the surface, it was only a matter of time before researchers noted a response in the deep sea (e.g. Thiel, 2003; Tyler, 2003; Glover and Smith, 2003). Destructive fishing practices, the serial removal of fish, the hunt for hydrocarbons and climate change are affecting deep-sea communities now. The lack of quantitative information from the deep-sea affects the conclusions that can be drawn on the extent, severity and persistence of these impacts. Therefore research now needs to shift from locating and describing disturbance to quantifying the impacts over temporal and spatial scales. This information is especially important for the development of truly effective conservation measures. Whether this is a realistic proposition in the deep sea is a question that remains to be answered. However, some of these impacts could be mitigated or even avoided by the development of appropriate regulatory controls, the establishment of relevant protected areas and improved awareness of the deep-sea environment among both policy makers and the general public.

\section{Protecting deep-sea biodiversity and ecosystems}

Marine protected areas have been established to protect biodiversity and enhance fisheries in coastal areas throughout the world (Gell and Roberts, 2003; Halpern, 2003; Roberts et al., 2005a). These areas provide refuges for populations of exploited and vulnerable species or habitats by exerting strong control over human activity (Gell and Roberts, 2003). Such as placing restrictions on fishing gear, oil and gas prospecting or other human activities such as dumping. Many coastal marine protected areas have shown significant benefits since their establishment. Fisheries often increase adjacent to the reserves due to the emigration of adults and juveniles and the export of pelagic eggs and larvae (Bohnsack, 1998; Murawski et al., 2000; Tawake et al., 2001). Inside reserves, populations of many species often increase in abundance and individuals live longer with increased reproductive potential (Bohnsack, 1990; Gell and Roberts, 2003; Halpern, 2003). Sessile species that are vulnerable to physical damage or harvesting can recover. For example, on 
the Georges Bank in the Gulf of Maine, populations of echinoderms, hydroids and seafans have increased in areas closed to trawling (NRC, 2002). It is likely that deep-sea protected areas would respond in a similar way although ecosystem connectivity and recovery timescales are less well understood. The process of applying protected area status to the deep sea represents a different set of challenges to those faced in terrestrial and coastal ecosystems.

Existing marine reserves have several key limitations, the most significant of which are size and location (Boersma and Parrish, 1999). The degree of protection a reserve can offer to a species can be assessed by its dispersal capability and how restricted the species is to a particular site (Kenchington, 1990). Species with low dispersal that are restricted to small areas are likely to be well protected by small reserves. However, highly mobile species may require extremely large reserves to provide adequate protection. Some estimates suggest that $50-90 \%$ of the total utilised habitat is needed (Clark, 1996; Lauck et al., 1998). The initial theory behind designing marine protected areas was developed for terrestrial systems and adapted for the coastal realm (Soulé and Terborgh, 1999; Carr et al., 2003). The designers of a reserve faces three immediate questions: (1) How large must the reserve be? (2) How many must there be? And (3) Where should they be located? (Carr et al., 2003). There are no single answers shared between terrestrial or coastal environments (Carr et al., 2003) and the answers are likely to be different again for deep-sea habitats and species. Especially since, significant legal, scientific and socio-economic issues face the development of effective deep-sea marine protected areas.

Although many deep-sea protected areas are likely to be within the exclusive economic zones of individual countries, there are many vulnerable species and habitats offshore on the High Seas. In these multiple user and multiple jurisdictional areas, the lack of effective legal frameworks makes the implementation and enforcement of protected areas more difficult (Gubbay, 1998). For example, it is currently possible for fishing vessels to avoid established regional fisheries management regulations by operating under flags of convenience (Gianni and Simpson, 2005). The countries to which vessels are registered are responsible for the actions of these vessels on the High Seas, but often exercise little or no control (Gianni and Simpson, 2005). These countries are often not registered with regional fisheries management organisations and currently, they cannot be held legally responsible for fishing activity under any regional management regulations. One example is in the Northeast Atlantic where only fishing vessels from Contracting Parties with the North East Atlantic Fisheries Commission (NEAFC) are legally bound to operate within established legalisation, such as effort reduction initiatives, no take zones and closed areas. Vessels flying flags of convenience from countries that are not registered with NEAFC and violate these regulations are not prosecutable under current legalisation. This form of unregulated fishing limits the ability of managers to enforce closed areas in international waters.

Scientific knowledge of the deep sea is continually improving but significant gaps remain. In particular, little is known about the dispersal of many deep-sea organisms, which has clear consequences for the placement and size of effective reserves (Shanks et al., 2003). Mapping coverage in the deep sea is low, with the majority of effort targeted towards areas containing clearly identifiable habitats such as cold-water coral reefs (e.g. Roberts et al., 2005b). Current distribution data of mobile species such as deep-sea fish are poor, with many migration routes and aggregation areas currently unknown (Haedrich et al., 2001). Without sound scientific knowledge, detailed species distributional and abundance data and physical habitat mapping, it is difficult to answer the three essential questions for effective reserve design posed by Carr et al. (2003).

One suggested solution is the development of a marine reserve network extending throughout coastal areas and the High Seas (Roberts et al., 2006a). Networks of protected areas could protect highly migratory species, and may even protect undiscovered habitats such as those associated with seamounts (Roberts et al., 2006a). Another potential mechanism to protect migratory deep-sea species could be mobile reserves that would follow sensitive species along migration routes (Roberts et al., 2006a). In the deep sea, potentially the most immediately effective measure would be to allow fishing to continue in areas where fish stocks have reduced and benthic damage already occurred but to close other areas to new fishing to protect existing fish stocks and benthic habitats. However, this would need to be coupled with effort reductions in order to protect existing fish stocks which are rapidly diminishing (Baum et al., 2003; Morato et al., 2006). It is likely that any biologically sustainable deep-sea fish catches would be economically worthless.

There is still much to learn about the deep sea, making comparisons with existing coastal protected areas difficult. Coastal reserves are found within the exclusive economic zones of nations allowing the establishment of effective legalisation. Reserves in coastal areas often have significantly higher organism density, biomass and diversity than comparative control areas (Murawski et al., 2000; Halpern, 2003). It is likely the recovery of deep-sea habitats and fish stocks would occur, providing reserves are effectively designed and policed. Recovery would probably take longer, especially as many deep-sea species have slower growth rates, later sexual maturation and variable or infrequent recruitment, but there has been no research recording the effectiveness of deep-sea marine protected areas. There are many challenges surrounding the designation of protected status for deep-sea areas, but there could be extensive economic and social benefits for doing so, as outlined for shallow-water marine protected areas by Balmford et al. (2002, 2004).

\subsection{Protection initiatives}

Throughout the world, there are over 100000 designated protected areas covering a total area of 18.8 million $\mathrm{km}^{2}$. Of these, marine environments constitute 1.64 million $\mathrm{km}^{2}$, representing less than $0.5 \%$ of the global ocean surface (Chape et al., 2003). To date, only few deep-sea areas have been granted permanent protected status, often these areas contain focal species and habitats such as cold-water corals (See Table 1 and Freiwald et al., 2004) and hydrothermal vents (e.g. Endeavour Hydrothermal Vent Field, Canada). 


\begin{tabular}{|c|c|c|}
\hline Country/Area & $\begin{array}{c}\text { Year of } \\
\text { designation }\end{array}$ & Cold-water coral protection (Restrictions on bottom contact fishing gear/human activity) \\
\hline Australia & 1999 & Tasmanian Seamount Reserve. Seamounts (Commonwealth of Australia, 2002). \\
\hline $\begin{array}{l}\text { Azores, Madeira } \\
\text { and Canary Islands }\end{array}$ & 2004 & Deep-water coral reefs (European Council, 2004) \\
\hline \multirow[t]{3}{*}{ Canada } & 2002 & Northeast Channel Conservation Area. Deep-water coral (Department of Fisheries and Oceans, 2002) \\
\hline & 2004 & Stone Fence Fisheries Closure. Cold-water coral reefs (Department of Fisheries and Oceans, 2004) \\
\hline & 2004 & The Gully Marine Protected Area. Protection for all species including corals (Canada's Oceans Act, 2004) \\
\hline Europe & 2006 & Capo Santa Maria di Leuca. Lophelia reefs (FAO GFCM, 2006) \\
\hline New Zealand & 2001 & Seamounts management strategy, seamount fauna including corals (Brodie and Clark, 2004) \\
\hline \multirow[t]{5}{*}{ Norway } & 1999 & Sula Reef. Cold-water coral reefs (Norwegian Directorate of Fisheries, 2006) \\
\hline & 2000 & Iverryggen. Cold-water coral reefs (Norwegian Directorate of Fisheries, 2006) \\
\hline & 2003 & Røst Reef. Cold-water coral reefs (Norwegian Directorate of Fisheries, 2006) \\
\hline & 2003 & Tisler Reef. Cold-water coral reefs (Norwegian Directorate of Fisheries, 2006) \\
\hline & 2003 & Fiellknausene. Cold-water coral reefs (Norwegian Directorate of Fisheries, 2006) \\
\hline \multirow[t]{2}{*}{ USA } & 1984 & Oculina protected area. Oculina reefs, Florida. (South Atlantic Fishery Management Council, 1998) \\
\hline & 2005 & Aleutian Islands. Deep-sea corals. (Department of Commerce, 2006) \\
\hline UK & 2004 & Darwin Mounds, coral mounds (European Council, 2004) \\
\hline
\end{tabular}

Some areas have been granted temporary protection against potentially damaging activities such as fishing, for example the NEAFC placed a 2-year restriction on fishing gear type at five Mid-Atlantic Ridge Seamounts on the 1st January 2005 (NEAFC, 2004). Unlike these complex habitats, the majority of the deep sea appears a relatively featureless expanse of sediment, lacking in focal species and habitats. This does not mean these areas are of lower conservation value; rather, some estimates place them amongst the most diverse habitats on earth (Grassle and Maciolek, 1992; Gage, 1996). The focal species approach is potentially a powerful tool for conservation (King and Beazley, 2005). The rationale is that focal species may warrant conservation because they possess characteristics that identify them as functionally important, vulnerable or sensitive to disturbance.

Cold-water corals meet many of these criteria (King and Beazley, 2005) and are now receiving considerable conservation focus (see Freiwald et al., 2004; Morgan et al., 2006). The immediate protection of sensitive areas such as cold-water coral ecosystems may be a first step to developing a network of protected areas throughout the oceans. Over the last few years, bottom trawling has been identified as one of the most significant threats facing cold-water corals (Hall-Spencer et al., 2002; Gage et al., 2005; Grehan et al., 2005; Roberts et al., 2006b; Wheeler et al., 2005). This has led to significant publicity and lobbying to ban bottom trawling in areas of coral habitat. In late 2006, United Nations General Assembly called upon member states and regional fisheries management organisations to close areas to bottom fishing in areas where seamounts, hydrothermal vents and cold-water corals are known or are likely to occur based on scientific information (UN GA, Draft resolution of the 61st session of the General Assembly, 6th December 2006, A/61/L.38). This represents one of the first major international steps to protect vulnerable habitats in the deep sea.

\subsection{Case study: conserving cold-water corals}

Cold-water corals are an important flagship species for conservation in the deep sea (King and Beazley, 2005) that are becoming relatively well understood compared to other deep-sea habitats (Freiwald et al., 2004; Roberts et al., 2006b). Reef and mound features are diverse habitats. For example, one study examining 11 box-cores from carbonate mounds in the Porcupine Seabight reported 10 previously undescribed benthic invertebrates and found coral-rich cores from the mounds to be three times more species-rich than cores taken off mound (Henry and Roberts, 2007). Several countries are now actively protecting cold-water coral areas within their national waters (Table 1). Further offshore, the High Seas also contain many vulnerable habitats and new regulations are required to protect areas that lie in international waters. Currently, there is only one example of a permanently protected area in a region fished by several European Union member states and other licensed states.

The Darwin Mounds lie $180 \mathrm{~km}$ off the north-west of Scotland at ca. $900 \mathrm{~m}$ water-depth within the European Union Exclusive Economic Zone (Bett, 2001). These mounds are colonised by a diverse community of corals, suspension feeders and infauna (Masson et al., 2003; Van Gaever et al., 2004). Discovered in 1998, the mounds were designated an offshore marine protected area in 2004 after concerns about possible damage from hydrocarbon exploration and proven damage from bottom trawling (Wheeler et al., 2005). In 1999, Greenpeace campaigned to halt offshore oil and gas exploration to the west of the UK, leading to a High Court judgment that the European Community Habitats Directive is applicable throughout the UK's continental shelf and any waters within the 200 nautical mile limit of member states exclusive economic zones or exclusive fishing zones. Under the Habitats Directive, member states are required to take measures to maintain or restore certain specified natural habitats and wild species by assuring their protection. Reports concerning the increasing extent of trawling damage to seabed habitats at $1000 \mathrm{~m}$ depth on the European continental margin (Roberts et al., 2000; Hall-Spencer et al., 2002) and the detection of trawl marks across the Darwin Mounds in 2000 (Wheeler et al., 2005) led to growing calls for this area to be protected from further damage by prohibiting bottom trawling within the Darwin Mounds area. In 2003 this led to a formal request 
from the UK government to the European Commission for an emergency closure of the Darwin Mounds under the European Common Fisheries Policy (European Council, 2003a). The following year, the European Council announced that from August of 2004 an area of $1300 \mathrm{~km}^{2}$ around the Darwin Mounds would be permanently closed to bottom trawling (European Council, 2004) and the UK plans to designate the area as a special area of conservation (Annex 1, EC Habitats Directive) once enabling legalisation is in place.

\subsection{Enforcement of protected status}

It has become increasingly important that measures are developed to effectively manage and police deep-sea protected areas. Many, if not most, such areas are found miles offshore with no visual barriers or landmarks. In coastal areas, spotter planes, patrol vessels and onboard observers are often used to monitor protected areas. However, applying these methodologies to deep-sea monitoring may be prohibitively expensive and time-consuming, offering only limited spatial coverage. Some deep-sea fisheries use observer systems, such as Canadian vessels fishing for Greenland Halibut and the Falkland Island fisheries. One cost effective method is the emerging use of global positioning surveillance (Marr and Hall-Spencer, 2002; Deng et al., 2005; Murawski et al., 2005) or remotely sensed images (Kourti et al., 2001, 2005). These methodologies offer complete spatial coverage and may become increasingly cost effective in the long term.

Since 2002 European Union fishing vessels greater than $24 \mathrm{~m}$ in length (reduced to all vessels greater than $15 \mathrm{~m}$ in length since 2005) have been required to submit their position via GPS every two hours to a Fisheries Monitoring Centre (European Council, 2003b). Each European Union member state receives Vessel Monitoring System (VMS) data for vessels that are active within its exclusive economic zone and the global positions of vessels that are registered to that member state. At present these data are not used for deep- sea habitat protection, but they could be used as an additional tool for the spatial management of offshore fishing fleets (Deng et al., 2005; Murawski et al., 2005). There are, however, problems associated with this approach. There is often uncertainty over the type of fishing taking place which requires corroborative evidence such as visual sightings in closed areas (e.g. Kuruc, 2005) and VMS can be blocked or falsified, which is leading some government authorities to investigate the use of remotely sensed imagery as a complementary tool to support VMS evidence (Kourti et al., 2005).

The potential for VMS as a fisheries management tool in the deep sea can be illustrated using the Darwin Mounds closed area. Vessel monitoring system data collected during 2003 for fishing vessels $>24 \mathrm{~m}$ in length was supplied by the UK Department of Environment Food and Rural Affairs. The data were from all EU countries, including the Faeroe Islands and Norway and was filtered to retain the tracks of vessels travelling between 1.5 and 4.5 knots as deep-water trawlers cannot fish outside these speeds (J.D.M. Gordon, pers. comm.). Vessels travelling at trawling speeds were most active on the banks and slopes surrounding the Darwin Mounds province, with little fishing activity in the closed area (Fig. 3). There was a large increase in fishing activity recorded in the month before the closure (Fig. 3). It is possible that the announcement of the closure may have directed increased trawl effort into the Darwin Mounds protected area, with fishing effort (hours spent trawling) for 2003 increasing between July and August (Fig. 4). However, this conclusion may be misleading as comparison with data from 2002 shows a similar seasonal increase in fishing effort in August within the closed area (Fig. 4). Whilst there is no evidence for a reduction in overall effort throughout the overall area, the potential for VMS data as a monitoring and enforcement tool is great; it can graphically demonstrate breaches of area closures and could help to warn fishermen that they are about to enter a restricted area. Thus, VMS may become one of the most valuable tools available to monitor High Seas marine protected areas and assess fishing activity.
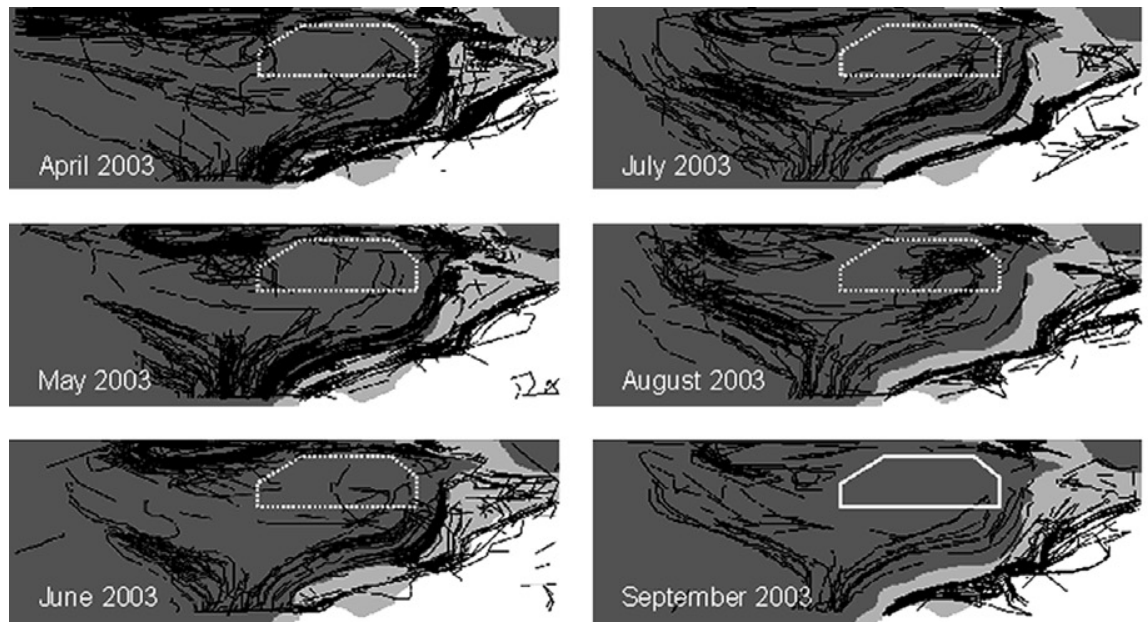
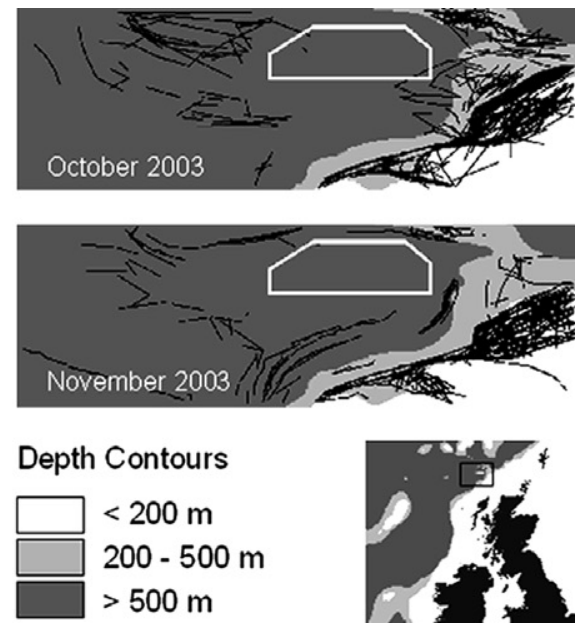

Fig. 3 - Monthly tracks of fishing vessels travelling at typical trawling speeds of 1.5-4.5 knots derived from VMS data for the Darwin Mounds box for 2003. The closed area is indicated by a white box (dashed line, pre-closure; solid line, post-closure). Inset map shows the location of the Darwin Mounds (white box). Bathymetry from Gebco (IOC et al., 2003). 


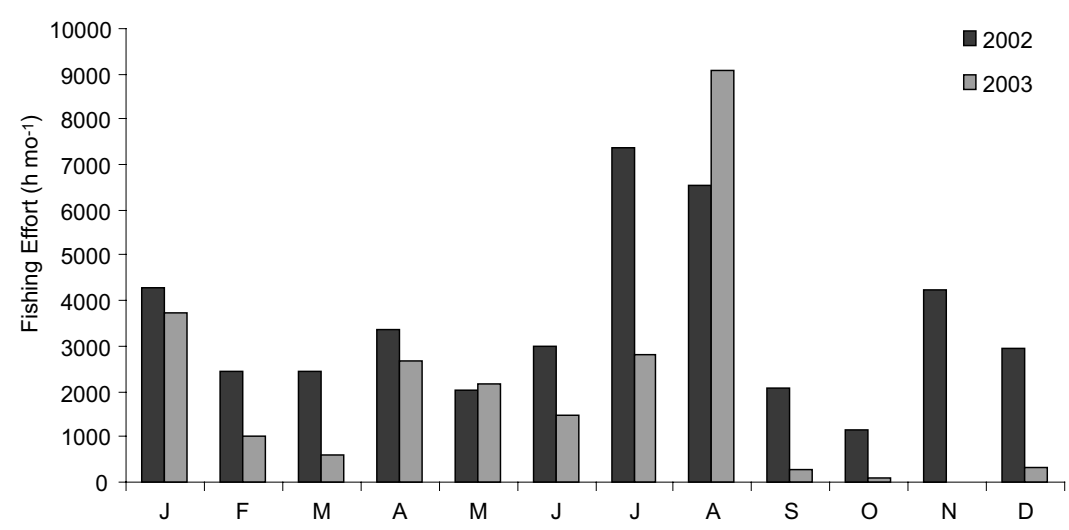

Fig. 4 - Fishing vessel effort (hours per month) within the Darwin Mounds area that was closed to trawling in September 2003 based on VMS data. This provides a minimum estimate of effort since vessels were assumed to be (a) travelling in straight line between position fixes that were received every 15-120 min and (b) trawling when travelling at speeds of 1.5-4.5 knots.

\section{Concluding comments}

As our understanding of deep-sea habitats improves, many more threats to these environments are uncovered. In recent years, bottom trawl fishing has been highlighted as one of the most significant, historical over-fishing and serial depletion of stocks has led to large collapses in fish stocks world-wide. Trawling is a well-recognised cause of habitat damage in deep-waters, especially to benthic ecosystems dominated by sessile corals and sponges. The ever-increasing search for new hydrocarbon resources and the emerging potential for $\mathrm{CO}_{2}$ storage in the deep-sea may have significant effects on deep-sea communities. On a global scale, climate change is becoming the most significant impact with a reach predicted to extend to the deepest parts of the ocean.

Successful management, protection and restoration of deep-sea habitats require a sound scientific basis, which is currently lacking. Increased mapping and basic ecological research is needed to understand the distribution and dispersal capabilities of deep-sea organisms which will assist in the design of marine reserves. Current protection, although improving, still needs to become more efficient with comprehensive legalisation and enforcement that can cover multi-jurisdictional areas such as the High Seas. Conservation measures must be monitored and enforced. The vessel monitoring system shows great potential as a tool to monitor fishing activities offshore and on the High Seas. The EU has identified the year 2012, as the target date to develop an ecologically coherent network of marine reserves. With so much of the earth affected by human activity, it is important to ensure that the deep sea, very probably the last great wilderness on earth, attains adequate protection to preserve it for future generations.

\section{Acknowledgements}

We are grateful to the following for permission to reproduce images: John Hartley and BP Ltd. (Fig. 1d), the Alfred-Wegener-Institut für Polar- und Meeresforschung and the Institut Français de Recherche pour l'Exploitation de la Mer, VIC-
TOR-Polarstern cruise ARKXIX/3a (Fig. 1c) and Lundin Petroleum Ltd. (Fig. 2). This work was supported by the Deep-sea Conservation for the United Kingdom project funded by the Esmée Fairbairn Foundation (Grant no. EN/04-3009) and the HERMES project (EC contract no. GOCE-CT-2005-511234), funded by the European Commission's Sixth Framework Programme under the priority 'Sustainable Development, Global Change and Ecosystems'. JH-S was funded by a Royal Society Research Fellowship. Genoveva Gonzales-Mirelis is thanked for GIS assistance and comments from John Gordon, John Hartley, Steve Hawkins and an anonymous reviewer improved an earlier version of the manuscript.

\section{R E F E R E N C E S}

Ball, B., Munday, B., Tuck, I., 2000. Effects of otter trawling on the benthos and environment in muddy sediments. In: Kaiser, M.J., Groot, S.J. (Eds.), Effects of fishing on non-target species and habitats. Blackwell, Oxford, pp. 69-82.

Balmford, A., Gravestock, P., Hockley, N., McClean, C.J., Roberts, C.M., 2004. The worldwide costs of marine protected areas. Proceedings of the National Academy of Sciences of the United States of America 101, 9694-9697.

Balmford, A., Bruner, A., Cooper, P., Costanza, R., Farber, S., Green, R.E., Jenkins, M., Jefferiss, P., Jessamy, V., Madden, J., Munro, K., Myers, N., Naeem, S., Paavola, J., Rayment, M., Rosendo, S., Roughgarden, J., Trumper, K., Turner, R.K., 2002. Ecology - economic reasons for conserving wild nature. Science 297, 950-953.

Barry, J.P., Buck, K.R., Lovera, C.F., Kuhnz, L., Whaling, P.J., Peltzer, E.T., Walz, P., Brewer, P.G., 2004. Effects of direct ocean $\mathrm{CO}_{2}$ injection on deep-sea meiofauna. Journal of Oceanography 60, 759-766.

Baum, J.K., Myers, R.A., Kehler, D.G., Worm, B., Harley, S.J., Doherty, P.A., 2003. Collapse and conservation of shark populations in the Northwest Atlantic. Science 299, 389-392.

Beardall, J., Raven, J.A., 2004. The potential effects of global climate change on microalgal photosynthesis, growth and ecology. Phycologia 43 (1), 26-40.

Bell, N., Smith, J., 1999. Coral growing on North Sea oil rigs. Nature 402, 601. 
Berkes, F., Hughes, T.P., Steneck, R.S., Wilson, J.A., Bellwood, D.R., Crona, B., Folke, C., Gunderson, L.H., Leslie, H.M., Norberg, J., Nyström, M., Olsson, P., Österblom, H., Scheffer, M., Worm, B., 2006. Globalization, roving bandits, and marine resources. Science 311, 1557-1558.

Bett, B.J., 2001. UK Atlantic Margin Environmental Survey: introduction and overview of bathyal benthic ecology. Continental Shelf Research 21, 917-956.

Bett, B.J., Malzone, M.G., Narayanaswamy, B.E., Wigham, B.D., 2001. Temporal variability in phytodetritus and megabenthic activity at the seabed in the deep Northeast Atlantic. Progress in Oceanography 50 (1-4), 349-368.

Boersma, P.D., Parrish, J.K., 1999. Limiting abuse: marine protected areas, a limited solution. Ecological Economics 31 (2), 287-304.

Bohnsack, J.A., 1990. The potential of marine fishery reserves for reef fish management in the US Southern Atlantic. NOAA. Technical Memo NMFS-SEFC-261. National Oceanic and Atmospheric Administration, Miami.

Bohnsack, J.A., 1998. Application of marine reserves to reef fisheries management. Australian Journal of Ecology 23, 298-304.

Brewer, P.G., 1997. Ocean chemistry of the fossil fuel $\mathrm{CO}_{2}$ signal: The haline signal of "business as usual". Geophysical Research Letters 24 (11), 1367-1369.

Brewer, P.G., Friederich, C., Peltzer, E.T., Orr, F.M., 1999. Direct experiments on the ocean disposal of fossil fuel $\mathrm{CO}_{2}$. Science 284, 943-945.

Brodie, S., Clark, M.R., 2004. The New Zealand seamount management strategy - steps towards conserving offshore marine habitat, In: Beumer, J.P., Grant, A., Smith, D.C. (Eds.), Aquatic Protected Areas: What Works Best and How Do We Know? Proceedings of the World Congress on Aquatic Protected Areas, Cairns, 2002. Australian Society for Fish Biology, Australia, pp. 664-673.

Brovkin, V., Bendtsen, J., Claussen, M., Ganopolski, A., Kubatzki, C., Petoukhov, V., Andreev, A., 2002. Carbon cycle, vegetation, and climate dynamics in the Holocene: experiments with the CLIMBER-2 model. Global Biogeochemical Cycles 16 (4). Art. No. 1139.

Carr, M.H., Neigel, J.E., Estes, J.A., Andelman, S., Warner, R.R., Largier, J.L., 2003. Comparing marine and terrestrial ecosystems: implications for the design of coastal marine reserves. Ecological Applications 13, S90-S107.

Caldeira, K., Wickett, M.E., 2003. Anthropogenic carbon and ocean pH. Nature 425, 365.

Caldeira, K., Wickett, M.E., 2005. Ocean model predictions of chemistry changes from carbon dioxide emissions to the atmosphere and ocean. Journal of Geophysical Research Oceans 110. Art. No. C09S04 2005.

Canada's Oceans Act, 2004. The Gully Marine Protected Area regulations. Canada Gazette 138 (May 19).

Chape, S., Blyth, S., Fish, L., Fox, P., Spalding, M., 2003. United Nations List of Protected Areas, IUCN, Gland, Switzerland and Cambridge, UK and UNEP-WCMC, Cambridge, UK.

Clark, C.W., 1996. Marine reserves and the precautionary management of fisheries. Ecological Applications 6 (2), 369-370.

Commonwealth of Australia, 2002. Tasmanian Seamounts Marine Reserve management plan. Environment Australia, Canberra.

Danovaro, R., Dell'Anno, A., Fabiano, M., Pusceddu, A., Tselepides, A., 2001. Deep-sea ecosystem response to climate changes: the eastern Mediterranean case study. Trends in Ecology \& Evolution 16, 505-510.

Danovaro, R., Dell'Anno, A., Pusceddu, A., 2004. Biodiversity response to climate change in a warm deep sea. Ecology Letters 7, 821-828.

Deng, R., Dichmont, C., Milton, D., Haywood, M., Vance, D., Hall, N., Die, D., 2005. Can vessel monitoring system data also be used to study trawling intensity and population depletion? The example of Australia's northern prawn fishery. Canadian Journal of Fisheries and Aquatic Sciences 62, 611-622.

Department of Commerce, 2006. Fisheries of the Exclusive Economic Zone off Alaska: Groundfish, Crab, Salmon, and Scallop Fisheries of the Bering Sea and Aleutian Islands Management Area and Gulf of Alaska. Department of Commerce Federal Register, Rules and Regulations 71, 36694-36714.

Devine, J.A., Baker, K.D., Haedrich, R.L., 2006. Deep-sea fishes qualify as endangered. Nature 439, 29.

Department of Fisheries and Oceans, 2002. Backgrounder: deep-sea coral research and conservation in offshore Nova Scotia. DFO Communications (Accessed at http:// www.mar.dfo-mpo.gc.ca/communications/maritimes/ back02e/B-MAR-02-(5E).html, 8 November 2006).

Department of Fisheries and Oceans, 2004. News Release: closure to protect deep water coral reef. DFO Communications (Accessed at http://www.mar.dfo-mpo.gc.ca/communications/ maritimes/news04e/NR-MAR-04-14E.html, 8 November 2006).

Diaz, R.J., Solan, M., Valente, R.M., 2004. A review of approaches for classifying benthic habitats and evaluating habitat quality. Journal of Environmental Management 73, 165-181.

Edwards, M., Reid, P., Planque, B., 2001. Long-term and regional variability of phytoplankton biomass in the Northeast Atlantic (1960-1995). ICES Journal of Marine Science 58 (1), $39-49$.

European Council, 2003a. Commission Regulation (EC) No 1475/ 2003 of 20 August 2003 on the protection of deep-water coral reefs from the effects of trawling in an area north west of Scotland. Official Journal L211, 14-15.

European Council, 2003b. Council Regulation (EEC) No. 2244/2003 of 18 December 2003 laying down detailed provisions regarding satellite-based Vessel Monitoring Systems. Official Journal (L333/17), 17-27.

European Council, 2004. Council Regulation (EEC) No. 602/2004 of 22 March 2004 amending regulation (EC) No. 850/98 as regards the protection of deepwater coral reefs from the effects of trawling in an area north west of Scotland. Official Journal L97, 30-31.

FAO (Food and Agriculture Organisation), 2004. The state of the world fisheries and aquaculture 2004. Food and Agriculture Organisation, Rome.

FAO, GFCM (Food and Agriculture Organisation, General Fisheries Commission for the Mediterranean), 2006. Report of the thirtieth session. Istanbul, 24-27 January 2006. GFCM Report 30, 2056 pp.

Feely, R.A., Sabine, C.L., Lee, K., Berelson, W., Kleypas, J., Fabry, V.J., Millero, F.J., 2004. Impact of anthropogenic $\mathrm{CO}_{2}$ on the $\mathrm{CaCO}_{3}$ system in the oceans. Science 305, 362-366.

Fosså, J.H., Mortensen, P.B., Furevik, D.M., 2002. The deep-water coral Lophelia pertusa in Norwegian waters: distribution and fishery impacts. Hydrobiologia 471, 1-12.

Freiwald, A., Fosså, J.H., Grehan, A., Koslow, T., Roberts, J.M., 2004. Cold-water coral reefs. UNEP-WCMC, Cambridge, UK. 84 pp.

French, L.S., Richardson, G.E., Kazanis, E.G., Montgomery, T.M., Bohannon, C.M., Gravois, M.P., 2006. Deep-water Gulf of Mexico 2006: America's expanding frontier. U.S. Department of the Interior, Minerals Management Service, Gulf of Mexico OCS Region, New Orleans, 148 pp.

Furevik, D.M., Fosseidengen, J.E., 2000. Investigation on naturally and deliberately lost gillnets in Norwegian waters. Working Document to the Fisheries Technology Fish Behaviour Group. Harlem Netherlands.

Gage, J.D., 1996. Why are there so many species in deep-sea sediments? Journal of Experimental Marine Biology and Ecology 200, 257-286. 
Gage, J.D., Tyler, P.A., 1991. Deep-sea biology: a natural history of organisms at the deep-sea floor. Cambridge University Press, Cambridge, MA.

Gage, J.D., Roberts, J.M., Hartley, J.P., Humphery, J.D., 2005. Potential impacts of deep-sea trawling on the benthic ecosystem along the Northern European Continental Margin: a review. In: Barnes, P.W., Thomas, J.P. (Eds.), Benthic Habitats and the Effects of Fishing. American Fisheries Society, Bethesda, MD, pp. 503-517.

Gass, S.E., Roberts, J.M., 2006. The occurrence of the cold-water coral Lophelia pertusa (Scleractinia) on oil and gas platforms in the North Sea: colony growth, recruitment and environmental controls on distribution. Marine Pollution Bulletin 52, 549-559.

Gell, F.R., Roberts, C.M., 2003. Benefits beyond boundaries: the fishery effects of marine reserves. Trends in Ecology \& Evolution 18, 448-455.

Gianni, M., 2004. High-seas bottom fisheries and their impact on the biodiversity of vulnerable deep-sea ecosystems. IUCN, $90 \mathrm{pp}$.

Gianni, M., Simpson, W., 2005. The changing Nature of High Seas fishing: how flags of convenience provide cover for illegal, unreported and unregulated fishing. Australian Department of Agriculture, Fisheries and Forestry, International Transport Workers' Federation and WWF International, $88 \mathrm{pp}$.

Glover, A.G., Smith, C.R., 2003. The deep-sea floor ecosystem: current status and prospects of anthropogenic change by the year 2025. Environmental Conservation 30, 219-241.

Gooday, A.J., 2002. Biological responses to seasonally varying fluxes of organic matter to the ocean floor: a review. Journal of Oceanography 58, 305-332.

Graf, G., 1989. Benthic-pelagic coupling in a deep-sea benthic community. Nature 341, 437-439.

Grassle, J.F., Maciolek, N.J., 1992. Deep-sea species richness: regional and local diversity estimates from quantitative bottom samples. American Naturalist 139, 313-341.

Grehan, A.J., Unnithan, V., Olu-Le Roy, K., Opderbecke, J., 2005. Fishing impacts on deepwater coral reefs: making a case for coral conservation. In: Barnes, P.W., Thomas, J.P. (Eds.), Benthic Habitats and the Effects of Fishing. American Fisheries Society, Bethesda, MD, pp. 819-832.

Gubbay, S., 1998. Management of offshore marine protected areas. A report for WWF-UK.

Guinotte, J.M., Orr, J.C., Cairns, S.D., Morgan, L., George, R., 2006. Will human-induced changes in seawater chemistry alter the distribution of deep-sea scleractinian corals? Frontiers in Ecology and the Environment 4, 141-146.

Haedrich, R.L., Merrett, N.R., O'Dea, N.R., 2001. Can ecological knowledge catch up with deep-water fishing? A North Atlantic perspective. Fisheries Research 51, 113-122.

Hall-Spencer, J., Allain, V., Fosså, J.H., 2002. Trawling damage to Northeast Atlantic ancient coral reefs. Proceedings of the Royal Society of London Series B - Biological Sciences 269, 507-511.

Hallock, J.L., Tharakan, P.J., Hall, C.A.S., Jefferson, M., Wu, W., 2004. Forecasting the limits to the availability and diversity of global conventional oil supply. Energy 29, 1673-1696.

Halpern, B.S., 2003. The impact of marine reserves: do reserves work and does reserve size matter? Ecological Applications 13, S117-S137.

Hansen, B., Østerhus, S., Quadfasel, D., Turrell, W., 2004. Already the day after tomorrow? Science 305, 953-954.

Hareide, N.-R., Garnes, G., Rihan, D., Mulligan, M., Tyndall, P., Clark, M., Connolly, P., Misund, R., McMullen, P., Furevik, D.M., Humborstad, O.-B., Høydal, K., Blasdale, T., 2005. A Preliminary Investigation on Shelf Edge and Deep-sea Fixed Net Fisheries to the West and North of Great Britain, Ireland, around Rockall and Hatton Bank. Bord Iascaigh Mhara, Fiskeridirecktoratet, NEAFC, Sea Fish Industry Authority, Joint Nature Conservation Committee, Marine Institute Foras na Mara, 47 pp.
Hartley, J.P., 2005. The challenge of deep water oilfield environmental monitoring west of Britain. In: Armsworthy, S.L., Crawford, P.J., Lee, K. (Eds.), Offshore oil and gas environmental effects monitoring: approaches and technologies. Batelle Press, Columbus, pp. 449-473.

Hawkins, S.J., Southward, A.J., Genner, M.J., 2003. Detection of environmental change in a marine ecosystem - evidence from the western English Channel. Science of the Total Environment 310 (1-3), 245-256.

Haugan, P.M., Turley, C., Poertner, H.O., 2006. Effects on the marine environment of ocean acidification resulting from elevated levels of $\mathrm{CO}_{2}$ in the atmosphere. DN-utredning 2006-1, Norwegian Directorate for Nature Management (Available from: http://www.dirnat.no/attachment.ap?id=130, Accessed 10 November 2006).

Heinze, C., 2004. Simulating oceanic $\mathrm{CaCO}_{3}$ export production in the greenhouse. Geophysical Research Letters 31 (16). Art. No. L16308.

Henry, L.-A., Roberts, J.M., 2007. Biodiversity and ecological composition of macrobenthos on cold-water coral mounds and adjacent off-mound habitat in the bathyal Porcupine Seabight, NE Atlantic. Deep-sea Research Part I: Oceanographic Research Papers, vol. 54, pp. 654-672.

Holloway, S., 2005. Underground sequestration of carbon dioxide a viable greenhouse gas mitigation option. Energy 30, 2318-2333.

House, K.Z., Schrag, D.P., Harvey, C.F., Lackner, K.S., 2006. Permanent carbon dioxide storage in deep-sea sediments. Proceedings of the National Academy of Sciences of the United States of America 103, 12291-12295.

Hovland, M., Vasshus, S., Indreeide, A., Austdal, L., Nilsen, $\varnothing$., 2002. Mapping and imaging deep-sea coral reefs off Norway, 1982-2000. Hydrobiologia 471, 13-17.

Hughes, D.J., Gage, J.D., 2004. Benthic metazoan biomass, community structure and bioturbation at three contrasting deep-water sites on the northwest European continental margin. Progress In Oceanography 63, 29-55.

Humborstad, O.-B., Løkkeborg, S., Hareide, N.-R., Furevik, D.M., 2003. Catches of Greenland halibut (Reinhardtius hippoglossoides) in deepwater ghost-fishing gillnets on the Norwegian continental slope. Fisheries Research 64 (2-3), 163-170.

Husebø, A., Nøttestad, L., Fosså, J.H., Furevik, D.M., Jørgensen, S.B., 2002. Distribution and abundance of fish in deep-sea coral habitats. Hydrobiologia 471, 91-99.

IOC, IHO, BODC, 2003. Centenary edition of the GEBCO digital atlas, published on CD-ROM on behalf of the Intergovernmental Oceanographic Commission and the International Hydrographic Organization as part of the General Bathymetric Chart of the Oceans, British Oceanographic Data Centre, Liverpool, UK.

IPCC, 2001. Climate Change 2001: impacts, adaptation and vulnerability. In: McCarthy, J.J., Canziani, O.F., Leary, N.A., Dokken, D.J., White, K.S. (Eds.), Intergovernmental Panel on Climate Change Third Assessment Report. Cambridge University Press, Cambridge, MA.

ISA (International Seabed Authority), 2006. Statement of Satya N. Nandan, Secretary-General of the International Seabed Authority. Agenda Item 71, 61st Session of the General Assembly of the United Nations, 7th December 2006.

Ishimatsu, A., Hayashi, M., Lee, K.S., Kikkawa, T., Kita, J., 2005. Physiological effects on fishes in a high- $\mathrm{CO}_{2}$ world. Journal of Geophysical Research - Oceans, 110. Art. No. C09S09.

Kemp, A.G., Stephen, L., 2005. Optimizing oil and gas depletion in the maturing North Sea with growing import dependence. Oxford Review of Economic Policy 21, 43-66.

Kenchington, R.A., 1990. Guidelines for establishing marine protected areas. IUCN, Gland. 79 pp. 
King, M.C., Beazley, K.F., 2005. Selecting focal species for marine protected area network planning in the Scotia-Fundy region of Atlantic Canada. Aquatic Conservation - Marine and Freshwater Ecosystems 15, 367-385.

Kleypas, J.A., Feely, R.A., Fabry, V.J., Langdon, C., Sabine, C.L., Robbins, L.L., 2006. Impacts of ocean acidification on coral reefs and other marine calcifiers: a guide for future research. Report of a workshop held 18-20 April 2005, St. Petersburg, FL, sponsored by NSF, NOAA, and the U.S. Geological Survey.

Koslow, J.A., Boehlert, G.W., Gordon, J.D.M., Haedrich, R.L., Lorance, P., Parin, N., 2000. Continental slope and deep-sea fisheries: implications for a fragile ecosystem. ICES Journal of Marine Science 57, 548-557.

Koslow, J.A., Gowlett-Holmes, K., Lowry, J.K., O’Hara, T., Poore, G.C.B., Williams, A., 2001. Seamount benthic macrofauna off southern Tasmania: community structure and impacts of trawling. Marine Ecology - Progress Series 213, 111-125.

Kourti, N., Shepherd, I., Schwartz, G., Pavlakis, P., 2001. Integrating spaceborne SAR imagery into operational systems for fisheries monitoring. Canadian Journal of Remote Sensing 27, 291-305.

Kourti, N., Shepherd, I., Greidanus, H., Alvarez, M., Aresu, E., Bauna, T., Chesworth, J., Lemoine, G., Schwartz, G., 2005. Integrating remote sensing in fisheries control. Fisheries Management and Ecology 12, 295-307.

Kuruc, M., 2005. Vessel Monitoring System (VMS) proves the case in court. In: Shotton, R. (Ed.), Deep Sea 2003: Conference on the Governance and Management of Deep-sea Fisheries, Part 1: Conference Reports. Food and Agriculture: Fisheries Proceedings 3/1. Queenstown, New Zealand, pp. 342-362.

Lampitt, R.S., 1985. Evidence for the seasonal deposition of detritus to the deep-sea floor and its subsequent resuspension. Deep-Sea Research 32A, 885-897.

Lauck, T., Clark, C.W., Mangel, M., Munro, G.R., 1998. Implementing the precautionary principle in fisheries management through marine reserves. Ecological Applications 8 (1), S72-S78.

Levin, L.A., Etter, R.J., Rex, M.A., Gooday, A.J., Smith, C.R., Pineda, J., Stuart, C.T., Hessler, R.R., Pawson, D., 2001. Environmental influences on regional deep-sea species diversity. Annual Review of Ecology and Systematics 32, 51-93.

McAllister, D.E., Baquero, J., Spiller, G., Campbell, R., 1999. A global trawling ground survey. Marine Conservation Biology Institute, World Resources Institute and Ocean Voice International, Ottawa, Canada.

Marr, S., Hall-Spencer, J.M., 2002. UK coral reefs. The Ecologist 32, 36-37.

Masson, D.G., Bett, B.J., Billett, D.S.M., Jacobs, C.L., Wheeler, A.J., Wynn, R.B., 2003. The origin of deep-water, coral-topped mounds in the northern Rockall Trough, Northeast Atlantic. Marine Geology 194, 159-180.

Menzies, R.J., 1965. Conditions for the existence of life on the abyssal sea floor. Oceanography and Marine Biology: An Annual Review 3, 195-210.

Milliman, J.D., 1993. Production and accumulation of calciumcarbonate in the ocean - budget of a nonsteady state. Global Biogeochemical Cycles 7 (4), 927-957.

Morato, T., Watson, R., Pitcher, T.J., Pauly, D., 2006. Fishing down the deep. Fish and Fisheries 7, 24-34.

Morgan, L., Taso, C.-F., Guinotte, J.M., 2006. Status of deep-sea corals in US waters, with recommendations for their conservation and management. Marine Conservation Biology Institute, Bellevue, WA.

Murawski, S.A., Brown, R., Lai, H.L., Rago, P.J., Hendrickson, L., 2000. Large-scale closed areas as a fishery-management tool in temperate marine systems: The Georges Bank experience. Bulletin of Marine Science 66, 775-798.
Murawski, S.A., Wigley, S.E., Fogarty, M.J., Rago, P.J., Mountain, D.G., 2005. Effort distribution and catch patterns adjacent to temperate MPAs. ICES Journal of Marine Science 62, 1150-1167.

NEAFC (North East Atlantic Fisheries Commission), 2004. Report of the 23rd Annual Meeting of the North-East Atlantic Fisheries Commission, 8-12 November 2004. Vol. 1: Main Report. NEAFC, London, 42 pp.

Norwegian Directorate of Fisheries, 2006. Regulations amending the regulations relating to sea-water fisheries. (Accessed: http://www.fiskeridir.no/fiskeridir/english/regulations/ 061221_regulations_amending_the_regulations_ relating_to_sea_water_fisheries, 8 November 2006).

NRC (National Research Council), 2002. Effects of Trawling and Dredging on Seafloor Habitat. National Academy Press, Washington, DC.

Orr, J.C., Fabry, V.J., Aumont, O., Bopp, L., Doney, S.C., Feely, R.A., Gnanadesikan, A., Gruber, N., Ishida, A., Joos, F., Key, R.M., Lindsay, K., Maier-Reimer, E., Matear, R., Monfray, P., Mouchet, A., Najjar, R.G., Plattner, G.K., Rodgers, K.B., Sabine, C.L., Sarmiento, J.L., Schlitzer, R., Slater, R.D., Totterdell, I.J., Weirig, M.F., Yamanaka, Y., Yool, A., 2005. Anthropogenic ocean acidification over the twenty-first century and its impact on calcifying organisms. Nature 437, 681-686.

Palanques, A., Guillén, J., Puig, P., 2001. Impact of bottom trawling on water turbidity and muddy sediment of an unfished continental shelf. Limnology and Oceanography 46, 1100-1110.

Palanques, A., Martin, J., Puig, P., Guillén, J., Company, J.B., Sardà, F., 2006. Evidence of sediment gravity flows induced by trawling in the Palamos (Fonera) submarine canyon (northwestern Mediterranean). Deep-sea Research Part I: Oceanographic Research Papers 53, 201-214.

Pawson, M.G., 2003. The catching capacity of lost static fishing gears: introduction. Fisheries Research 64 (2-3), 101-105.

Pfannkuche, O., 1992. Organic carbon flux through the benthic community in the temperate abyssal northeast Atlantic. In: Rowe, G.T., Pariente, V. (Eds.), Deep-sea food chains and the global carbon cycle. Kluwer Acdemic Publishers, Dordrecht, pp. 183-198.

Pfannkuche, O., 1993. Benthic response to the sedimentation of particulate organic matter at the BIOTRANS station, $47^{\circ} \mathrm{N}$, $20^{\circ} \mathrm{W}$. Deep-sea Research Part I: Oceanographic Research Papers 40 (1-2), 135-149.

Pitcher, C.R., Poiner, I.R., Hill, B.J., Burridge, C.Y., 2000. Implications of the effects of trawling on sessile megazoobenthos on a tropical shelf in Northeastern Australia ICES Journal of Marine Science 57, 1359-1368.

Pitois, S.G., Fox, C.J., 2006. Long-term changes in zooplankton biomass concentration and mean size over the Northwest European shelf inferred from Continuous Plankton Recorder data. ICES Journal of Marine Science 63 (5), 785-798.

Raven, J., Caldeira, K., Elderfield, H., Hoegh-Guldberg, O., Liss, P., Riebesell, U., Shepherd, J., Turley, C., Watson, A., 2005. Ocean acidification due to increasing atmospheric carbon dioxide. The Royal Society, London.

Riebesell, U., Zondervan, I., Rost, B., Tortell, P.D., Zeebe, R.E., Morel, F.M.M., 2000. Reduced calcification of marine plankton in response to increased atmospheric $\mathrm{CO}_{2}$. Nature 407, 364-367.

Roberts, C.M., 2002a. Deep impact: the rising toll of fishing in the deep sea. Trends in Ecology \& Evolution 17, 242-245.

Roberts, J.M., 2002b. The occurrence of the coral Lophelia pertusa and other conspicuous epifauna around an oil platform in the North Sea. Underwater Technology 25, 83-91.

Roberts, C.M., Hawkins, J.P., Gell, F.R., 2005a. The role of marine reserves in achieving sustainable fisheries. Philosophical Transactions of the Royal Society B - Biological Sciences 360, 123-132. 
Roberts, C.M., Mason, L., Hawkins, J.P., 2006a. Roadmap to recovery: a global network of marine reserves. Greenpeace International, Amsterdam.

Roberts, J.M., Wheeler, A.J., Freiwald, A., 2006b. Reefs of the deep: The biology and geology of cold-water coral ecosystems. Science 213, 543-547.

Roberts, J.M., Brown, C.J., Long, D., Bates, C.R., 2005b. Acoustic mapping using a multibeam echosounder reveals cold-water coral reefs and surrounding habitats. Coral Reefs 24, 654-669.

Roberts, J.M., Harvey, S.M., Lamont, P.A., Gage, J.D., Humphery, J.D., 2000. Seabed photography, environmental assessment and evidence for deep-water trawling on the continental margin west of the Hebrides. Hydrobiologia 441, 173-183.

Rogers, A.D., 1999. The biology of Lophelia pertusa (LINNAEUS 1758) and other deep-water reef-forming corals and impacts from human activities. International Review of Hydrobiology 84, 315-406.

Ruhl, H.A., Smith, K.L., 2004. Shifts in deep-sea community structure linked to climate and food supply. Science 305, 513-515.

Sabine, C.L., Feely, R.A., Gruber, N., Key, R.M., Lee, K., Bullister, J.L., Wanninkhof, R., Wong, C.S., Wallace, D.W.R., Tilbrook, B., Millero, F.J., Peng, T.H., Kozyr, A., Ono, T., Rios, A.F., 2004. The oceanic sink for anthropogenic $\mathrm{CO}_{2}$. Science 305 , 367-371.

Sancho, G., Puente, E., Bilbao, A., Gomez, E., Arregi, L., 2003. Catch rates of monkfish (Lophius spp.) by lost tangle nets in the Cantabrian Sea (northern Spain). Fisheries Research 64 (2-3), 129-139.

Scheffer, M., Carpenter, S., Foley, J.A., Folke, C., Walker, B., 2001. Catastrophic shifts in ecosystems. Nature 413, 591-596.

Schippers, P., Lürling, M., Scheffer, M., 2004. Increase of atmospheric $\mathrm{CO}_{2}$ promotes phytoplankton productivity. Ecology Letters 7 (6), 446-451.

Seibel, B.A., Walsh, P.J., 2003. Biological impacts of deep-sea carbon dioxide injection inferred from indices of physiological performance. Journal of Experimental Biology 206, 641-650.

Shanks, A.L., Grantham, B.A., Carr, M.H., 2003. Propagule dispersal distance and the size and spacing of marine reserves. Ecological Applications 13, S159-S169.

Smith, K.L., Kaufmann, R.S., 1999. Long-term discrepancy between food supply and demand in the deep eastern North Pacific. Science 284, 1174-1177.

Soltwedel, T., 1997. Temporal variabilities in benthic activity and biomass in the western European continental margin. Oceanologica Acta 20, 871-879.

Soulé, M.E., Terborgh, J., 1999. Conserving nature at regional and continental scales - a scientific program for North America. Bioscience 49, 809-817.

South Atlantic Fishery Management Council (SAFMC), 1998. Amendment 4 to the Coral, Coral Reefs and Live/Hard Bottom Habitat Fishery Management Plan. Comprehensive Amendment Addressing Essential Fish Habitat in Fishery Management Plans of the South Atlantic Region.

Stephens, J.C., Van der Zwaan, B., 2005. The case for carbon capture and storage. Issues in Science and Technology 22, 68-76.

Tamburri, M.N., Peltzer, E.T., Friederich, G.E., Aya, I., Yamane, K., Brewer, P.G., 2000. A field study of the effects of $\mathrm{CO}_{2}$ ocean disposal on mobile deep-sea animals. Marine Chemistry 72, 95-101.

Tawake, A., Parks, J., Radikedike, P., Aalbersberg, B., Vuki, V., Salafsky, N., 2001. Harvesting clams and data involving local communities in monitoring can lead to conservation success in all sorts of unanticipated ways: a case in Fiji. Conservation in Practice 2, 32.
Thiel, H., 2003. Anthropogenic impacts on the deep sea, In: Tyler, P.A. (Ed.), Ecosystems of the Deep Ocean. Ecosystems of the World 28, pp. 427-471.

Thistle, D., Carman, K.R., Sedlacek, L., Brewer, P.G., Fleeger, J.W., Barry, J.P., 2005. Deep-ocean, sediment-dwelling animals are sensitive to sequestered carbon dioxide. Marine Ecology Progress Series 289, 1-4.

Thistle, D., Sedlacek, L., Carman, K.R., Fleeger, J.W., Brewer, P.G., Barry, J.P., 2006. Simulated sequestration of industrial carbon dioxide at a deep-sea site: effects on species of harpacticoid copepods. Journal of Experimental Marine Biology and Ecology 330, 151-158.

Tunnicliffe, V., 1991. The biology of hydrothermal vents - ecology and evolution. Oceanography and Marine Biology 29, 319-407.

Turley, C.M., Lochte, K., Lampitt, R.S., 1995. Transformations of biological particles during sedimentation in the northeastern Atlantic. Proceedings of the Royal Society of London Series B - Biological Sciences 348, 179-189.

Turley, C.M., Roberts, J.M., Guinotte, J., in press. Corals in deep water: Will the unseen hand of ocean acidification destroy cold water ecosystems? Coral Reefs.

Tyler, P.A., 1988. Seasonality in the deep-sea. Oceanography and Marine Biology: An Annual Review 26, 227-258.

Tyler, P.A., 2003. Disposal in the deep sea: analogue of nature or faux ami? Environmental Conservation 30, 26-39.

UKOOA, 2002. UKOOA drill cutting initiative final report, In UKOOA Drill Cutting Initiative Reports 2002 [CD-ROM].

UKOOA, 2005. Striking a balance 2005: The sustainability strategy update and progress report of the UK offshore oil and gas industry.

UN (United Nations), 1982. The law of the sea: United Nations Convention on the law of the sea, with index and final act of the third United Nations Convention on the law of the sea. United Nations. 10th December 1982.

UN (United Nations), 1996. The Law of the Sea: United Nations Convention on the Law of the Sea: Agreement relating to the Implementation of Part XI of the United Nations Convention of the Law of the Sea, United Nations. 10th December 1982.

Van Gaever, S., Vanreusel, A., Hughes, J.A., Bett, B., Kiriakoulakis, $\mathrm{K}$., 2004. The macro- and micro-scale patchiness of meiobenthos associated with the Darwin Mounds (north-east Atlantic). Journal of the Marine Biological Association of the United Kingdom 84, 547-556.

Walther, G.R., Post, E., Convey, P., Menzel, A., Parmesan, C., Beebee, T.J.C., Fromentin, J.M., Hoegh-Guldberg, O., Bairlein, F., 2002. Ecological responses to recent climate change. Nature 416, 389-395.

Wheeler, A.J., Bett, B.J., Billett, D.S.M., Masson, D.G., Mayor, D., 2005. The impact of demersal trawling on Northeast Atlantic deepwater coral habitats: The case of the Darwin Mounds, United Kingdom. In: Barnes, P.W., Thomas, J.P. (Eds.), Benthic Habitats and the Effects of Fishing. American Fisheries Society, Bethesda, MD, pp. 807-817.

Worm, B., Sandow, M., Oschlies, A., Lotze, H.K., Myers, R.A., 2005. Global patterns of predator diversity in the open oceans. Science 309, 1365-1369.

Yamazaki, T., Barnett, B., Suzuki, T., 1997. Optical determination of the JET deep sea sediment disturbance, In: Proceedings of the International Symposium on Environmental Studies of Deep-Sea Mining. Metal Mining Agency of Japan, Tokyo, Japan, pp. 153-168.

Zhu, C. 2004. Asia gunning for deep-sea oil and gas. (Accessed: http://www.planetark.org/dailynewsstory.cfm/newsid/26469/ story.htm, 20 November 2006).

Zondervan, I., Zeebe, R.E., Rost, B., Riebesell, U., 2001. Decreasing marine biogenic calcification: a negative feedback on rising atmospheric $\mathrm{pCO}_{2}$. Global Biogeochemical Cycles 15 (2), 507-516. 